in June 1981 and covered five years. "Being a small company, we can't be involved in everything," he says. Celltech intends to specialize in diagnostics, process reagents, culture products, health care and industrial microbiology. In the latter two fields, it will concentrate on genetically engineered products.
The company derives its original scientific impetus from an agreement with Britain's Medical Research Council, in whose laboratories Cesar Milstein carried out the basic work on monoclonal antibodies. Celltech now has a staff of more than 100 , about a third of them at Ph.D. level.

-Martin Sherwood

\title{
$\triangle$ THE BIO/TECHNOLOGY INDEX OF SPECIALTY FIRMS
}

Many of our readers interested in biotechnology want to follow the stock prices of biotechnology companies, although there does not seem to be a way to clearly define the status of that mythical animal called the biotechnology company. In fact, there are no biotechnology companies in the strict sense; public companies deeply involved with biotechnology all sell products or methods for manufacturing products rather than technology.

In our attempt to methodically track stock prices, we have discovered four truisms from our friends on Wall Street: there is a great deal of interest in comparing stock prices of so-called biotechnology companies; there is no definitive way to group these companies together or determine whether certain fringe companies using new biotechnologies should qualify; it is not meaningful to compare specialty firms with multinationals that are heavily dependent on biotechnology; and, although there is value in grouping companies together for comparison, the value is limited.

In order to heed vox populi and reveal some of the meaningful trends that can become apparent when analyzing data in a set format, $\mathrm{BIO} /$ TECHNOLOGY introduces its index of specialty firms. Without pretense of scientific accuracy, we have conveniently grouped specialty companies according to emphasis on recombinant DNA technology, antibody production technologies, and other products or technologies for product development.

$\mathrm{BIO} / \mathrm{TECHNOLOGY}$ used several criteria in choosing companies for the index: the company must have been trading on U.S. stock exchanges as of July 15,1983 , must emphasize origi- nal research using advanced biological techniques, and must support the development of products. By these criteria, equipment supply companies have been excluded from the list. Our index also omits multinationals with heavy investment in biotech research simply because the relationship between their technology development and their overall success is not as direct as it is with specialty firms. Subsidiaries also pose definitional problems; unless a subsidiary acts as its own business entity, it is not included in the index. Based on this fairly arbitrary criterion, Damon Biotech (70 percent owned by Damon Corp.) is included, while Viragen (90 percent owned by Automated Medical Laboratories) and Viratek (80 percent owned by ICN Pharmaceuticals) are omitted.

By definition, an index is a weighted average. The $\mathrm{BIO} / \mathrm{TECHNOLO}$ GY stock index is weighted by capitalization; a company with a greater number of outstanding shares has a greater influence on the index. In effect, the percent change in the index between any two points is equal to the percent change of the average share of stock of the companies included in the index.

The $\mathrm{BIO} / \mathrm{TECHNOLOGY}$ Index of Specialty Firms is useful for comparing the change in particular stocks to the change in the "average share" of the specialty firm stocks in the index. Christopher G. Edwards

BN/TECHNOLOGY INDEX OF SPECANT FIRMS

\begin{tabular}{|c|c|c|c|c|c|}
\hline & $\begin{array}{l}\text { Price } \\
\text { July } 15\end{array}$ & $\begin{array}{l}\text { Price } \\
\text { Aug. } 15\end{array}$ & $\begin{array}{l}\text { Percent } \\
\text { Change }\end{array}$ & $\begin{array}{l}52 \text { Week } \\
\text { Hi-Low }\end{array}$ & $\begin{array}{l}\text { Market Capitalization } \\
\text { in } \$ \text { millions (stock } \\
\text { price } \times \text { number of } \\
\text { shares outstanding) }\end{array}$ \\
\hline \multicolumn{6}{|l|}{ Companies Emphasizing } \\
\hline $\begin{array}{l}\text { Amgen } \\
\text { Ams }\end{array}$ & $133 / 8$ & $93 / 4$ & -27 & $18-93 / 4$ & 98 \\
\hline Bio Logicals & $41 / 2$ & $33 / 4$ & -17 & $61 / 2-2$ & 22 \\
\hline Biogen & $15 \% / 1$ & $143 / 4$ & -6 & $241 / 1-14 \% / 4$ & 273 \\
\hline Biotech Research Labs & $151 / 4$ & $13 \%$ & -10 & $211 / 2-23 / 1$ & 70 \\
\hline Biotechnica International & $12 \frac{1}{2}$ & $91 / 2$ & -24 & $171 / 1-81 / 2$ & 36 \\
\hline Cetus & $171 / 4$ & $13 \% / 4$ & -20 & $19-73 / 4$ & 302 \\
\hline Collaborative Research & 13 & $121 / 2$ & -4 & $151 / 2-8$ & 124 \\
\hline Enzo Biochem & 30 & $281 / 2$ & -5 & $341 / 1-51 / 1$ & 248 \\
\hline Genentech & $463 / 4$ & $441 / 2$ & -5 & $493 / 4-18$ & 632 \\
\hline Genex & $191 / 4$ & $215 / 8$ & +12 & $231 / 4-7$ & 277 \\
\hline Molecular Genetics & $183 / 4$ & 17 & -9 & $23-5$ & 104 \\
\hline \multirow{2}{*}{\multicolumn{6}{|c|}{$\begin{array}{l}\text { Companies Emphasizing } \\
\text { Antibody Production Technologies }\end{array}$}} \\
\hline & & & & & \\
\hline Bio-Response & 14 & $141 / 2$ & +4 & $161 / 8-31 / 8$ & 115 \\
\hline Cambridge BioScience & $113 / 4$ & $71 / 1$ & -38 & $171 / 4-6$ & 30 \\
\hline Centocor & $171 / 2$ & 16 & -9 & $251 / 2-131 / 2$ & 112 \\
\hline Damon Biotech & 16 & 13 & -19 & $171 / 2-12$ & 250 \\
\hline Genetic Systems & 14 & $113 / 4$ & -16 & $173 / 1-23 / 8$ & 231 \\
\hline Hybritech & $271 / 1$ & $241 / 2$ & -10 & $31-107 / 8$ & 252 \\
\hline Monoclonal Antibodies & $18 \% / 4$ & $161 / 2$ & -12 & $281 / 2-8$ & 40 \\
\hline Summa Medical & $145 / 8$ & $121 / 4$ & -16 & $15 \% / 8-3$ & 94 \\
\hline \multicolumn{6}{|c|}{$\begin{array}{l}\text { Companies Emphasizing Other Products } \\
\text { or Biotechnologies }\end{array}$} \\
\hline Genetic Engineering Inc. & $85 / 8$ & $63 / 4$ & -22 & $107 / 8-21 / x$ & 16 \\
\hline Immunex & $131 / 4$ & $10 \% / 2$ & -21 & $133 / 4-91 / 4$ & 60 \\
\hline Interferon Sciences & $85 / 8$ & $71 / 2$ & -13 & $11-27 / 8$ & 30 \\
\hline Ribi Immunochem & 13 & 10 & -23 & $161 / 2-21 / 16$ & 30 \\
\hline
\end{tabular}

